\title{
Novel roles of prolactin and estrogens in breast cancer: resistance to chemotherapy
}

\author{
Elizabeth W LaPensee and Nira Ben-Jonathan
}

Department of Cancer and Cell Biology, University of Cincinnati, 3125 Eden Avenue, Cincinnati, Ohio 45267-0521, USA

(Correspondence should be addressed to N Ben-Jonathan; Email: nira.ben-jonathan @uc.edu)

\begin{abstract}
Resistance to chemotherapy is a major complication in the treatment of advanced breast cancer. Estrogens and prolactin (PRL) are implicated in the pathogenesis of breast cancer but their roles in chemoresistance have been overlooked. A common feature to the two hormones is activation of their receptors by diverse compounds, which mimic or antagonize their actions. The PRL receptor is activated by lactogens (PRL, GH, or placental lactogen) originating from the pituitary, breast, adipose tissue, or the placenta. Estrogen receptors exist in multiple membrane-associated and cytoplasmic forms that can be activated by endogenous estrogens, man-made chemicals, and phytoestrogens. Here, we review evidence that low doses of PRL, estradiol $\left(E_{2}\right)$, and bisphenol $A$ (BPA) antagonize multiple anticancer drugs that induce cell death by different mechanisms. Focusing on cisplatin, a DNA-damaging drug which is effective in the treatment of many cancer types but not breast cancer, we compare the abilities of PRL, $E_{2}$, and BPA to antagonize its cytotoxicity. Whereas PRL acts by activating the glutathione-S-transferase detoxification enzyme, $\mathrm{E}_{2}$ and BPA act by inducing the antiapoptotic protein Bcl-2. The implications of these findings to patients undergoing chemotherapy are discussed.
\end{abstract}

Endocrine-Related Cancer (2010) 17 R91-R107

\section{Introduction}

Each year, over a million women worldwide are diagnosed with breast cancer, accounting for $25 \%$ of all female cancers. Treatments include surgery, radiation therapy, chemotherapy, or their combinations. Neoadjuvant chemotherapy is used to reduce tumor size before surgery, while adjuvant chemotherapy is used after tumor excision. Chemotherapy is the mainstay treatment for patients with triple negative tumors (estrogen receptor (ER), progesterone receptor (PR), and human epidermal growth factor receptor 2 (Her-2)) who are resistant to hormone or targeted therapy, and for those with advanced metastatic disease (Coley 2008). Dozens of anticancer drugs have been developed, with treatment options taking into account tumor grade and histology and whether the desired outcome is curative or palliative. Most regimens combine drugs that act by different mechanisms aimed at improving the odds of suppressing tumor growth (Ocana \& Pandiella 2008).

While both the selection and success of chemotherapeutic agents have increased, tumor resistance remains a major obstacle, which results in treatment failure. Some tumors are intrinsically resistant to certain drugs, while others acquire resistance following treatment. Resistance can result from drug efflux by transporters, inactivation by detoxification enzymes, altered expression of pro/antiapoptotic proteins, changes in tumor suppressor genes, and increased DNA repair mechanisms (Coley 2008). Whereas hormones such as prolactin (PRL) and estradiol $\left(\mathrm{E}_{2}\right)$ have long been implicated in the pathogenesis of breast cancer, their involvement in chemoresistance has been overlooked. The objective of this review is to evaluate emerging evidence that these hormones confer resistance against a variety of chemotherapeutic agents that kill breast cancer cells by different mechanisms and discuss the clinical implications.

PRL and estrogens are dissimilar in chemical structure, receptor characteristics, and signaling mechanisms. Whereas estrogens can bind to several classical $(E R \alpha$ and $E R \beta)$ and nonclassical (G protein-coupled receptor 30, GPR30) receptors (Manavathi \& Kumar 2006), there is only one receptor (PRLR) for PRL, albeit it exists in several isoforms which couple to different signaling pathways (Swaminathan et al. 2008). Yet, there is crosstalk between the two hormones, with PRL 
increasing the expression and phosphorylation of ER $\alpha$ (Carver et al. 2009), and $\mathrm{E}_{2}$ inducing the transcription of both PRL (Duan et al. 2008) and the PRLR (Swaminathan et al. 2008). Such interactions can result in augmentation, or synergism, between the two hormones.

Several features that are common to PRL and $\mathrm{E}_{2}$ confound the understanding of their roles in breast cancer. One is the multiple sites of origin, with both hormones reaching the breast from the systemic circulation as well as from local sources (Ben-Jonathan et al. 2002, Foster 2008). Thus, blood levels of PRL or $E_{2}$ do not reveal the full extent of breast exposure to these hormones. Another is a variable expression of their receptors in tumors, which often depends upon the luminal or basal origin of the tumor. Thus, neither hormone affects tumors that do not express its receptor. Importantly, 80-90\% of breast carcinomas express the PRLR (Touraine et al. 1998), while $\sim 75 \%$ contain $\mathrm{ER} \alpha$ (Karayiannakis et al. 1996). This indicates that most breast tumors express both receptors, reinforcing their importance as therapeutic targets. Finally is the issue of receptor promiscuity, with ERs capable of binding steroidal and nonsteroidal compounds (Bai \& Gust 2009), and the PRLR capable of binding other lactogens (Goffin et al. 2005). Thus, xenoestrogens can mimic or antagonize endogenous estrogens, while GH and placental lactogen (PL) can augment or interfere with PRL actions. Figure 1 illustrates the various compounds that affect breast cancer via their interactions with either the PRLR or ERs.

\section{Properties of selected chemotherapeutic drugs}

Over the past 20-30 years, treatment of metastatic breast cancer has evolved from the anthracyclines to taxanes to hormonal and targeted therapy and their combinations (Coley 2008). Here, we focus on those drugs that are affected by PRL and/or estrogens.

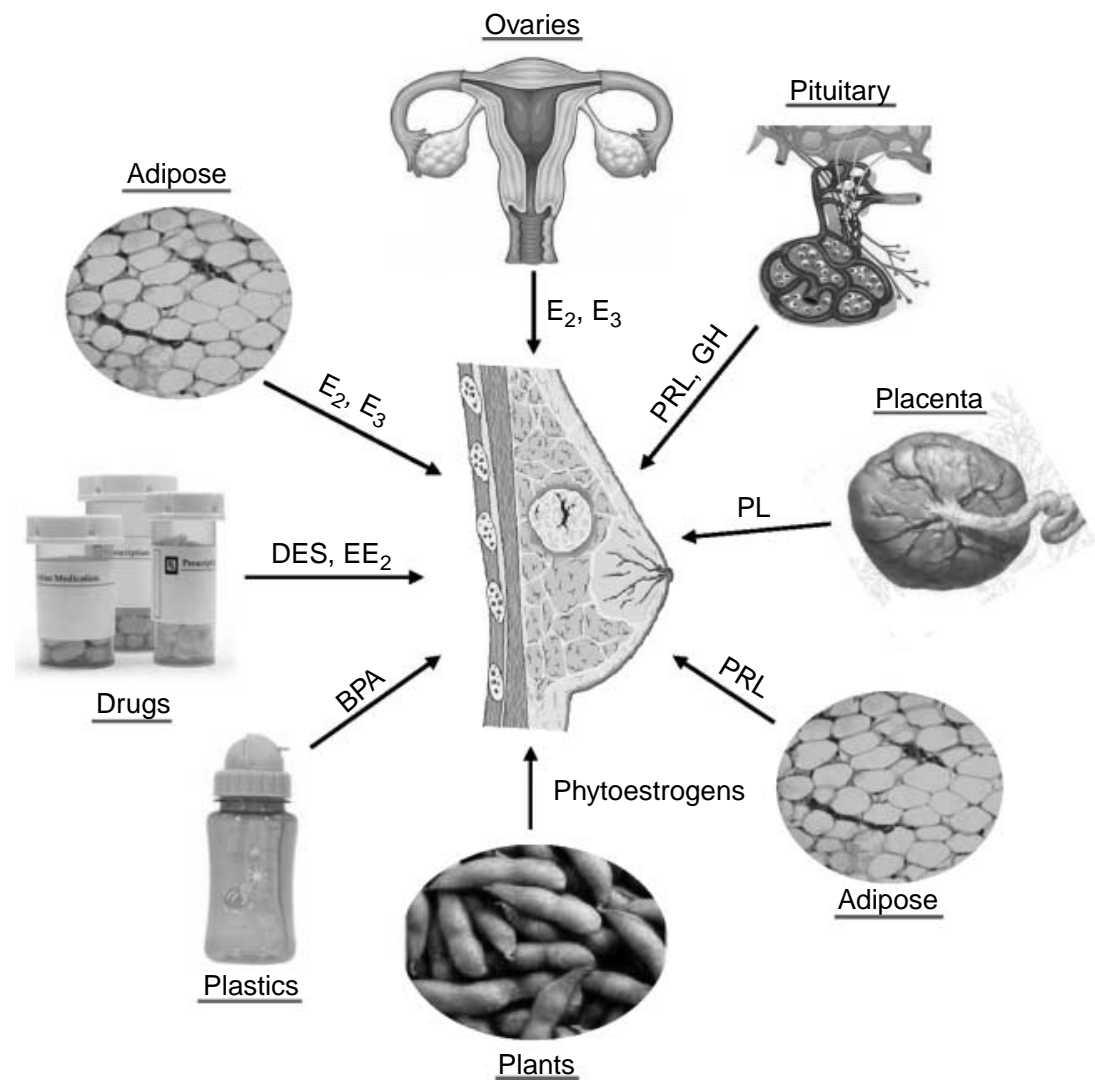

Figure 1 Diagram of the different compounds and their sites of origin which affect breast cancer by activating either the prolactin $(\mathrm{PRL})$ receptor (PRLR) or estrogen receptors (ERs). The right side of the illustration depicts the three structurally related lactogens, prolactin (PRL), GH, and placental lactogen $(P L)$, which bind to the PRLR. The left side shows the variety of compounds which activate either classical or nonclassical ERs. These include natural estrogens: estradiol $\left(E_{2}\right)$ and estriol $\left(E_{3}\right)$; man-made chemicals, diethylstilbestrol (DES), ethinylestradiol $\left(E_{2}\right)$, and bisphenol A (BPA); and phytoestrogens. Adipose tissue represents the stromal compartment within the breast as well as abdominal and subcutaneous depots. Both PRL and estrogens (likely via aromatization) are also produced within tumor cells themselves, where they act as autocrine/paracrine agents. 
Cisplatin is a platinum-based drug that is highly effective against testicular, ovarian, and lung cancers but has limited efficacy as monotherapy in breast cancer patients (Decatris et al. 2004). Following uptake into the nucleus, cisplatin interacts with DNA and forms adducts via intrastrand cross-links that induce cell cycle arrest. The DNA can either be repaired by the nucleotide excision pathway, or the cell is destined to die (Kelland 2007). The caspase 3-deficient MCF7 cells are not killed by cisplatin (Blanc et al. 2000), although cisplatin can induce apoptosis via a caspase 3 -independent mechanism in ovarian cancer cells (Henkels \& Turchi 1999).

Doxorubicin (adriamycin) is an anthracycline antibiotics used in multiple cancers, and is considered the standard treatment in breast cancer. Upon entering the nucleus, doxorubicin inhibits topoisomerase II and helicase activities, and interferes with DNA double helix religation. This stops DNA replication and induces apoptosis (Rabbani et al. 2005). Apoptosis may occur via activation of pro-apoptotic proteins, since antisense against $\mathrm{Bcl}-2$ and $\mathrm{Bcl}-\mathrm{xL}$ sensitizes breast cancer cells to this drug (Simoes-Wust et al. 2002). Doxorubicin can also cause replicative senescence, as evident by micronuclei formation and senescence-associated $\beta$-galactosidase staining (Chang et al. 2002).

Taxol (paclitaxel) has been highly successful in treating breast and ovarian cancer, especially in combination with anthracyclines. Taxol targets the microtubules, which mediate alignment of the chromosomes along the equatorial plane prior to segregation to daughter cells. It binds to polymerized tubulin and inhibits microtubule disassembly, thereby suppressing both microtubule treadmilling and dynamic instability (Zhou \& Giannakakou 2005). Taxol-induced apoptosis often correlates with phosphorylation of Bcl-2 (Ferlini et al. 2003). Apoptosis can occur via caspase 3-dependent or -independent mechanisms (Friedrich et al. 2001).

Vinblastine, a vinca alkaloid, is another microtubule-altering drug. Unlike taxol, it binds to monomeric tubulin and prevents its polymerization. Mitosis is blocked at the metaphase/anaphase transition, and the prolonged arrest leads to cell death (Zhou \& Giannakakou 2005). Vinblastine also interferes with amino acid, cAMP, and glutathione metabolism, and can induce apoptosis through the nuclear factor $\kappa \mathrm{B} /$ inhibitor of $\kappa \mathrm{B}(\mathrm{NF}-\kappa \mathrm{B} / \mathrm{I} \kappa \mathrm{B})$ pathway (Huang et al. 2004). Apparently, c-Jun protects T47D cells from vinblastine-induced cell death, although it does not prevent the mitotic block (Duan et al. 2007). At nontoxic doses, vinblastine inhibits chemotaxis and endothelial cell proliferation, highlighting its antiangiogenic properties (Vacca et al. 1999).

Apoptotic signals are also mediated via the tumor necrosis factor (TNF) family of death receptors. The TNF-related apoptosis-inducing ligand (TRAIL) induces oligomerization of the intracellular domains (ICDs) of the death receptors and causes apoptosis in many cancer cell types without killing normal cells (Wang \& El Deiry 2003). In recent clinical trials, TRAIL agonists showed no major toxicity, but therapy is limited to patient with TRAIL-sensitive tumors (Bellail et al. 2009).

The dependence of tumor expansion and metastasis on angiogenesis has lead to the development of angiogenesis blockers, which inhibit the release of pro-angiogenic proteins such as VEGF, block mitogenic/survival pathways of endothelial cells, or prevent extracellular matrix breakdown (Sessa et al. 2008). Over 300 angiogenic inhibitors have been developed, and dozens are in various phases of clinical trials. Avastin, an anti-VEGF monoclonal antibody, was the first antiangiogenic drug shown to prolong patient survival.

\section{Mechanisms of chemoresistance}

Resistance to chemotherapy results from many causes, including drug extrusion by transporters, drug metabolism, increased antiapoptotic proteins, decreased pro-apoptotic proteins, and enhanced DNA damage repair. A major problem is that tumors often exhibit resistance to a diversity of chemotherapeutic agents, which act by different mechanisms.

Multidrug resistance transporters, which target structurally diverse drugs, are major contributors to drug resistance. The best characterized are members of the ATP-binding cassette transporters, which include P-glycoprotein, multidrug resistance protein 1 (MRP1), and breast cancer resistance protein (BCRP; Higgins 2007). P-glycoprotein confers resistance against taxol, vinblastine, doxorubicin, and etoposide, with over $40 \%$ of breast tumors expressing this transporter (Trock et al. 1997). MRP1 confers resistance against anthracyclines, antifolates, and vinca alkaloids, but not against taxanes or cisplatin (Trock et al. 1997). Although originally isolated from a drug-resistant MCF7 subline, the BCRP protein is rarely found in $\mathrm{E}_{2}$-responsive cells, because of its downregulation by estrogens (Imai et al. 2005).

The glutathione metabolic pathway confers resistance against environmental insults and drugs. Glutathione-S-transferases (GSTs) are phase II detoxification enzymes that catalyze the conjugation of 
glutathione to electrophilic compounds, resulting in easily extruded products (Townsend \& Tew 2003, McIlwain et al. 2006). They inactivate platinum drugs, doxorubicin, cyclophosphamide, and etoposide, but not antimicrotubule drugs. Some GST isozymes inhibit JNK1 via protein:protein interactions and inactivate drugs that act via the mitogen activated protein (MAP) kinase pathway even when they are not subject to conjugation with glutathione. GSTs are inducible enzymes classified by substrate specificity and intracellular distribution into several families, e.g. $\alpha, \mu, \pi$ and $\theta$ subtypes. Overexpression of GST $\pi$ is associated with drug resistance and poor patient survival, while mutations in GST $\mu$ and GST $\pi$ predispose the affected individuals to environmental carcinogens (Shiga et al. 1999).

Tumors can acquire drug resistance by overexpressing antiapoptotic proteins (e.g. Bcl-2 and Bcl-xL) or downregulating pro-apoptotic proteins (e.g. Bax). MCF7 cells, which express high levels of $\mathrm{Bcl}-2$, are less responsive to cisplatin, but become sensitized to the drug upon Bcl-2 downregulation by RNA interference (Yde \& Issinger 2006). Breast cancer cells that overexpress $\mathrm{Bcl}-\mathrm{xL}$ are less sensitive to paclitaxel, which correlates with failure of the drug to activate caspase 9 (Wang et al. 2005). In addition, Bax overexpression in MCF7 cells restores their sensitivity to various apoptotic agents. Higher Bax expression levels are detected in normal breast epithelium than in adjacent tumors (Bargou et al. 1996).

Mutations in tumor suppressors strongly influence cancer cells sensitivity to anticancer drugs. Alterations in p53 are the most common genetic changes in breast cancer, with specific mutations associated with resistance to doxorubicin (Aas et al. 1996). The tumor suppressor gene BRCA1 is also frequently mutated in breast cancer. It responds to DNA damage by affecting DNA damage repair. Loss of BRCA1 confers sensitivity to many DNA-damaging agents (Kennedy et al. 2004), and its knockdown results in a twofold increase in cell sensitivity to irofulven (Wiltshire et al. 2007).

\section{Characteristics of PRL and PRLR}

PRL is a 23-kDa hormone of pituitary origin whose main target is the breast, where it stimulates proliferation, differentiation, survival, and secretory activity (Ben-Jonathan et al. 2008). Depending upon the cell context and physiological conditions, PRL can exert opposite actions such as proliferation versus differentiation in both malignant and nonmalignant cells. PRL belongs to a family of proteins, named lactogens, which share structural homology and some overlapping functions. The most prominent members are PRL, GH, and PL, which are made of a single polypeptide chain with 2-3 intramolecular disulfide bridges. Lactogens have a high homology in their primary amino acids and a similar tertiary structure, composed of four antiparallel, up-up, down-down helical bundle (Teilum et al. 2005).

Unique to humans, PRL is also produced in multiple nonpituitary sites, including the decidua, myometrium, breast, and prostate (Ben-Jonathan et al. 1996). Whereas pituitary PRL is controlled by a proximal promoter which requires the pituitary-specific Pit-1 transcription factor for transactivation, expression of extrapituitary PRL is driven by a superdistal promoter (Gerlo et al. 2006). The insensitivity of the superdistal promoter to dopamine explains the failure of dopamine agonists, such as bromocriptine, to suppress breast PRL and affect PRL-dependent tumors in patients (Ben-Jonathan et al. 2008). Within the normal breast, PRL is produced at much larger quantities by stromal adipocytes than by the epithelium (Zinger et al. 2003) and is up-regulated in carcinomas as compared with benign breast epithelium (McHale et al. 2008).

The PRLR is a member of the cytokine receptor superfamily, which is nontyrosine kinase, single-pass membrane receptor. It has a three-domain organization: an extracellular ligand-binding domain, which confers specificity, a short transmembrane domain, and an ICD (Swaminathan et al. 2008, Clevenger et al. 2009). In addition to the most abundant $80 \mathrm{kDa}$ long isoform, shorter variants that couple to different signaling pathways are detectable in breast cancer. Among cell lines, T47D cells express the highest PRLR levels, followed by MCF7, BT483, MDA-MB468, and BT474 (Peirce et al. 2001). The human PRLR is indiscriminate in its binding preferences, with $\mathrm{GH}$ binding not only to its receptor (GHR) but also to the PRLR. In contrast, nonprimate GH binds only to the GHR, while PRL binds only to the PRLR but not to GHR in any species (Ben-Jonathan et al. 2008). PL does not have a receptor of its own and binds only to the PRLR (see Fig. 1).

Two binding sites on the ligand are required for PRLR activation. One receptor binds to a high affinity site 1 , while a second receptor binds to a lower affinity site. This forms an active ternary complex composed of one hormone molecule and receptor homodimer (Teilum et al. 2005). The existence of preformed, inactive dimers without a ligand suggests that receptor dimerization is necessary but insufficient for its activation (Clevenger et al. 2009). Ligand binding induces relative rotations of the two units, resulting in allosteric reorganization of the ICD. This brings the 
ICD and Jak2 kinase into close proximity, enabling their phosphorylation. The lactogens, which differ in critical interacting residues, do not induce identical conformational changes in the receptor (Gertler et al. 1996). Instead, each imposes a different stability on the active complex, thereby affecting its dynamics and binding parameters of the associated partners.

Several PRLR antagonists, made by modifications of the PRL molecule, have been generated, which block PRL actions in vitro and in experimental animals (Goffin et al. 2005). However, their use as an effective treatment in breast cancer patients is uncertain because of their short half-life and the necessity for their administration by injection. Efforts are underway to find small molecules that selectively block the PRLR and can be delivered orally.

Binding of PRL to its receptor activates several signaling pathways, of which the Jak2-Stat5 pathway is the best understood. Jak2 is rapidly activated by PRL and phosphorylates Stat proteins. These dimerize and translocate to the nucleus, where they bind to GAS elements within the promoters of target genes. Stat $5 \mathrm{a} / \mathrm{b}$ mediate many of the PRL actions in normal and malignant breast cells (Clevenger et al. 2009). PRL-responsive genes that are involved, directly or indirectly, in cell cycle regulation include cyclin D1, AP-1, c-Myc, and heat shock protein $\alpha$ (Brockman et al. 2002, Acosta et al. 2003, Gutzman et al. 2005, Perotti et al. 2008).

Although activation of the Jak2-Stat pathway is critical for lobuloalveolar development and lactation in the normal breast, other PRL-induced pathways are important in breast cancer. One is the Ras-Raf-MAPK pathway, with ERK1/2 and $c$-jun N-terminal kinase being its primary mediators. PRL induces phosphorylation of ERK1/2 in both T47D and MCF7 cells, and can synergize with epidermal growth factor (EGF) to induce ERK (Acosta et al. 2003). Activation of the phosphoinositide-3-kinase (PI3K)-Akt survival pathway by PRL has been implicated in cell migration (Maus et al. 1999). Crosstalk between PRLR and ER $\alpha$ occurs at several levels. For example, PRL and $E_{2}$ cooperatively enhance AP-1 activity (Gutzman et al. 2005), and $\mathrm{E}_{2}$ rapidly phosphorylates Stat5 (Fox et al. 2009), while PRL activates the unliganded ER (Gonzalez et al. 2009).

\section{Role of PRL in carcinogenesis}

The role of PRL in mammary tumorigenesis in rodents has long been recognized, while its involvement in breast cancer only recently became accepted. Prospective studies found a modest association between higher serum PRL levels and cancer risk in both premenopausal and postmenopausal women, primarily those with ER + tumors (Tworoger \& Hankinson 2008). However, shortcomings of epidemiological studies include single blood sample determination and assay standardization. Most importantly, they do not take into account the local production of PRL by the breast or the status of PRLR expression in the tumors.

PRL exerts multiple actions in breast cancer cells, including increased proliferation, enhanced motility, and prolonged survival. Suppression of T47D cell proliferation by PRL antisense oligos, anti-PRL antibodies, and PRLR antagonists served as the evidence for the mitogenic activity of autocrine PRL (Chen et al. 1999, Vonderhaar 1999, Llovera et al. 2000). The role of autocrine/paracrine PRL is supported by studies with nude mice, where growth of tumors derived from T47D cells is inhibited by treatment with the hPRL antagonist G129R (Chen et al. 2002), while PRL overexpressing MDA-MB-435 cells form faster growing tumors (Liby et al. 2003).

PRL also affects cytoskeleton modulation, as reveals by its enhancement of breast cancer cell migration and induction of PI3K-dependent membrane ruffling and stress fibers (Maus et al. 1999). PRL and its cleaved fragment 16K PRL can stimulate and inhibit angiogenesis respectively, suggesting an indirect role for PRL in carcinogenesis via alterations in tumor blood supply (Clapp et al. 2008). Of great importance is a recent report that mouse PRL does not activate the human PRLR (Utama et al. 2006), raising issues of interpretation of drug responsiveness of human xenografts in mice, which are unaffected by circulating PRL.

Unlike estrogen, PRL is only a modest mitogen in breast cancer. In fact, Stat 5 activation by PRL may be linked to induction of differentiation and suppression of invasion rather than to proliferation (Sultan et al. 2005). This is supported by a lower expression of activated Stat5 in node-positive breast cancer than in normal breast or less advanced tumors (Nevalainen et al. 2004). Yet, the argument that PRL acts solely as an antimetastatic factor is overreaching, since signaling pathways other than Stat5 are activated by PRL. PRL could serve as a suppressor of metastasis in advanced tumors but as a promoter of cell growth in early tumors. A switch between tumor promotion to suppression is exemplified by transforming growth factor- $\beta$ (TGF $\beta$ ), which inhibits the growth of normal epithelial cells but accelerates the malignant process of late-stage tumors (Bachman \& Park 2005). Estrogen represents another case of contrasting actions, since in addition to its mitogenic actions it can induce apoptosis under some conditions (Lewis-Wambi \& Jordan 2009). 


\section{PRL and chemoresistance}

Accumulating evidence suggests that PRL opposes cytotoxicity by a wide variety of anticancer drugs. In PC3 prostate cancer cells, TRAIL-induced apoptosis is partially inhibited by PRL, which by itself has no effect on cell proliferation (Ruffion et al. 2003). Another group reported that pretreatment of ovarian carcinoma cells with PRL inhibits cisplatin-induced cell death (Asai-Sato et al. 2005). PRL also antagonizes apoptosis caused by methotrexate, an antifolate agent, in human promyelocytic leukemia HL-60 cells (Hsu et al. 2006).

Epidemiological data suggest that women with elevated blood PRL levels have increased treatment failure and worse survival (Tworoger \& Hankinson 2008). Indeed, hyperprolactinemic patients with metastatic breast cancer are less responsive to taxol than those with normal serum PRL levels (Lissoni et al. 2001). A small clinical trial revealed better responsiveness in patients treated with a combination of taxol and bromocriptine, compared to those receiving only taxol (Lissoni et al. 2002). These data should be replicated in larger trials with PRL inhibitors (i.e. bromocriptine and cabergoline) together with various anticancer drugs. However, an effective blockade of the PRLR would likely be more effective in sensitizing tumors to anticancer drugs than the suppression of pituitary PRL release.

Several studies have focused on PRL as an anticytotoxic factor in breast cancer cells. Ramamoorthy et al. (2001) found that induction of apoptosis by cisplatin in T47D cells is enhanced by co-treatment with the hPRL antagonist G129R, suggesting that endogenous PRL is protective. Another antagonist, $\Delta 1-9-G 129 R-h P R L$, potentiates the effects of paclitaxel and doxorubicin in breast cancer cells (Howell et al. 2008). In addition, cells that produce PRL, e.g. T47D and MCF7, are more resistant to ceramideinduced apoptosis than those with low or no PRL (Perks et al. 2004). PRL can also overcome growth arrest caused by $\gamma$-irradiation (Chakravarti et al. 2005). None of the above studies, however, have resolved the mechanisms underlying the protective effects of PRL.

Our exploration of the mechanism by which PRL antagonizes anticancer drugs was inspired by the finding that PRL overexpression in MDA-MB-435 cells enhanced tumor growth and up-regulated Bcl-2 (Liby et al. 2003). Pretreatment of breast cancer cells with low doses of PRL antagonizes cytotoxicity by taxol, vinblastine, doxorubicin, and cisplatin, albeit at different efficacies (LaPensee et al. 2009b). We were especially interested in the mechanism by which PRL opposed cisplatin, which has shown only little effectiveness in breast cancer patients. Unlike its strong apoptotic effects in MDA-MB-468 cells, cisplatin is only moderately effective in T47D cells. Reasoning that the resistance of T47D cells may be due to their high endogenous PRL levels, the mechanistic studies were conducted with MDA-MB-468 cells.

Measurement of platinum in nuclear extract by mass spectroscopy reveals that PRL reduces the amount of cisplatin bound to DNA. Lower entry of cisplatin into the nucleus could be due to transporters such as MRP that extrude the drug, or to detoxification enzymes such as GST that inactivate cisplatin (Siddik 2003). Previous work showed that PRL increases hepatic GST activity (Luquita et al. 1999). Using inhibitors of the two potential targets, we discovered that GST, but not MRP, accounts for the suppression of cisplatin entry to the nucleus by PRL. This action is mediated by the Jak-Stat and MAPK pathways, but not by PI3K pathway. Subsequent studies show that PRL induces the expression of the GST $\mu$ isoform and increases GST enzyme activity in MDA-MB-468 cells (LaPensee et al. 2009b). The GST $\mu$ - and $\theta$-null genotypes are associated with increased survival in women with advanced breast cancer that were treated with chemotherapy (Ambrosone et al. 2001). Future studies should determine whether knockdown of specific GST isozymes abrogates the protective effects of PRL.

A model which conceptualizes the mechanism by which PRL confers resistance against cisplatin is presented in Fig. 2. After diffusing into the cell, cisplatin enters the nucleus and binds to DNA, with the ensuing cell cycle arrests leading to apoptosis. Binding of PRL to its receptor induces the activation of Jak-Stat and MAPK pathways, which separately or in concert increase the expression and activity of GST. GST conjugates cisplatin to glutathione, leading to its extrusion from the cell. Consequently, less cisplatin is available for entering the nucleus and inflicting DNA damage. The overall effect of PRL is a marked reduction in cisplatin-induced cell death. In addition to cisplatin, GST confers resistance to doxorubicin but not to the microtubule-altering drugs (L'Ecuyer et al. 2004). Thus, the mechanism by which PRL antagonizes drugs which are not substrates for GST may involve alterations in $\mathrm{Bcl}-2$ family proteins.

\section{Estrogens: multiple ligands and diverse receptors}

$E_{2}$, estriol, and estrone are naturally occurring estrogens, which differ in affinity for the various ERs. They have dissimilar bioactivities, with $\mathrm{E}_{2}$ being the most potent. From menarche to menopause, the ovaries 


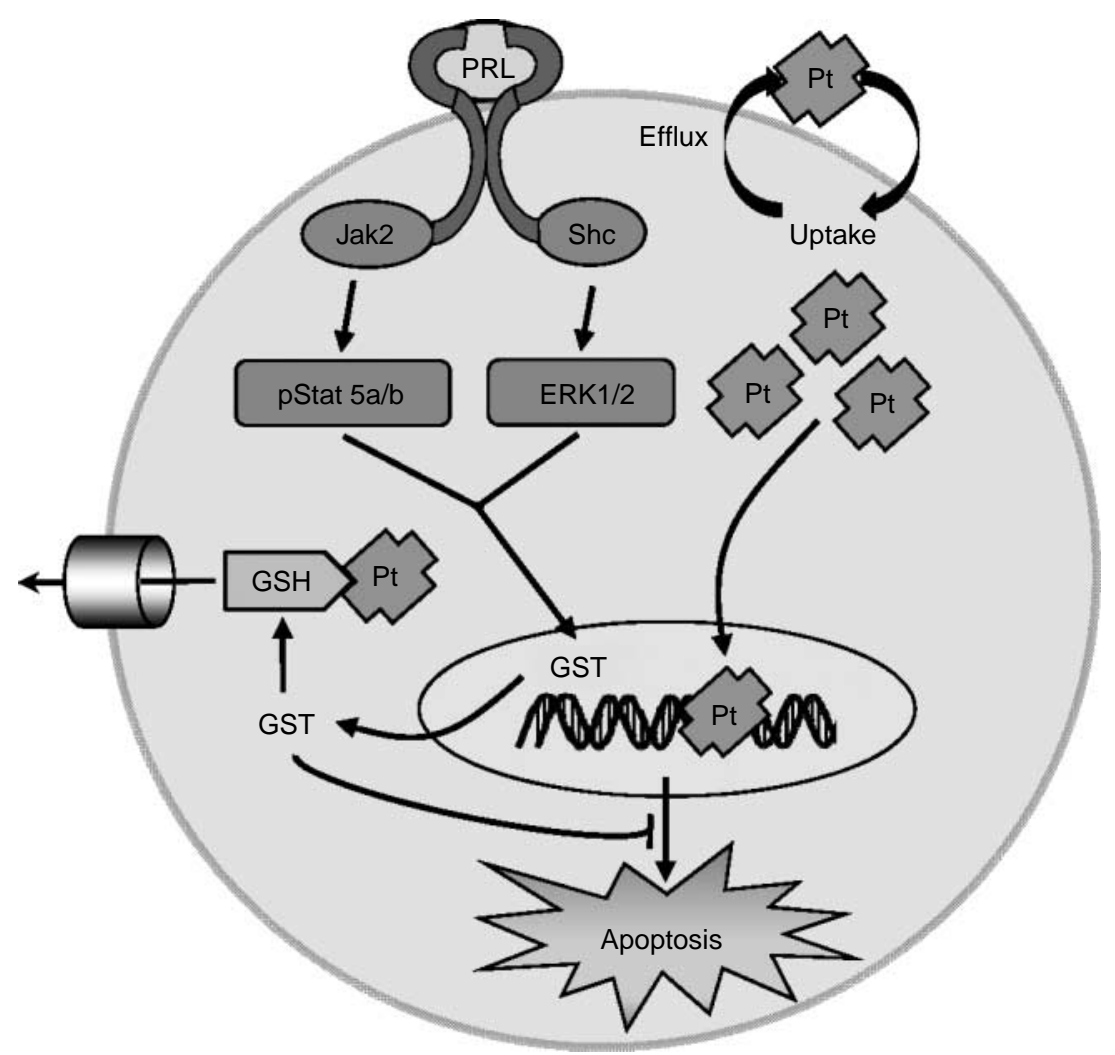

Figure 2 Proposed mechanism by which prolactin (PRL) antagonizes cisplatin-induced apoptosis in breast cancer cells. Cisplatin $(\mathrm{Pt})$ diffuses into the cell and enters the nucleus, where it binds to DNA, causes cell cycle arrest, and induces apoptosis. Binding of $\mathrm{PRL}$ to the receptor enables its association with Jak2 and Shc, and the subsequent signaling via Stat5a/b and ERK1/2 pathways. It is through either, or both, of these pathways that PRL increases transcription of the detoxification enzyme glutathione-S-transferase (GST). Increased GST activity promotes conjugation of glutathione (GSH) to cisplatin, followed by extrusion of the conjugate from the cell via transporters. Consequently, less cisplatin is available for entry into the nucleus, resulting in decreased apoptosis.

are the primary source of estrogens. After menopause, estrogens can be generated through the conversion of androgens secreted by the adrenals and the ovaries. This process is carried out in sites such as the skin and adipose tissue by the aromatase enzyme complex (Jongen et al. 2006; see Fig. 1).

Breast cancer expresses several sex steroidproducing enzymes, including aromatase, $17 \beta$-hydroxysteroid dehydrogenase, which catalyzes interconversion among estrogens, and steroid sulfatase, which hydrolyzes sulfated steroids to their bioactive forms (Suzuki et al. 2005). Although serum $\mathrm{E}_{2}$ levels in postmenopausal women are only 5-10\% of those before menopause, their tumors are exposed to comparable levels of active estrogens. Indeed, the tumor/plasma ratio of $E_{2}$ is $>20$ in breast carcinomas from postmenopausal women but only 5 in those from premenopausal women (Pasqualini et al. 1996). Aromatase inhibitors are effective in blocking the growth of early ER + tumors (Nabholtz et al. 2009). Similar to the higher production of PRL by breast stroma (Zinger et al. 2003), estrogen synthesis is higher in the stroma than in epithelial cells due to higher expression of aromatase (Santen et al. 1997).

As schematically illustrated in Fig. 1, endocrine disruptors that mimic or antagonize endogenous estrogens are relevant to breast cancer. Estrogen-like compounds include pesticides, industrial chemicals, pharmaceuticals, and plant-derived compounds, all of which can expose humans through food or water supply (Gray et al. 2009). Many are lipophilic and can be stored in adipose tissue. The most widely studied are components of plastics, e.g. bisphenol A (BPA; discussed in the next chapter), and detergents such as octyl and nonyl phenols. Chlorinated insecticides, e.g. kepone, dichloro diphenyl trichloroethane (DDT), dieldrin, and methoxychlor, also possess estrogenlike properties. Two unresolved issues are whether early exposure to endocrine disruptors increases the risk of developing breast cancer, and what is the effect of interactions between chemicals in mixtures (Birnbaum \& Fenton 2003, Gray et al. 2009). 
Diethylstilbestrol (DES) and ethinylestradiol are potent pharmaceuticals used to treat symptoms of menopause, as contraceptives and as palliative therapy in advanced prostatic cancer. Given the millions of users, home toilets are the major source of these compounds in wastewater (Falconer 2006). Although excreted into urine as inactive glucoronides or sulfates, some can be degraded in sewage treatment plants and release the active compounds.

Resveratrol, daidzein, quercetin, and genistein represent the most commonly ingested and intensely studied plant-derived phytoestrogens (Martin et al. 2007, Mense et al. 2008). They show differential binding to $E R \alpha$ and $E R \beta$, exert nongenomic actions, and also affect estrogen biosynthesis and metabolism. Although the general belief is that long-term consumption of phytoestrogens (i.e. soy products) helps in reducing a woman's risk of breast cancer, this notion is controversial (Martin et al. 2007, Gray et al. 2009).

Estrogens bind to multiple receptors of diverse structure that can be localized in the membrane, cytoplasm, and nucleus. $\mathrm{ER} \alpha$ and $\mathrm{ER} \beta$ differ in their ligand-binding domain, underlying the dissimilar binding affinities of the various estrogenic ligands to the two receptors. ER $\alpha$ is expressed at low levels in the normal breast epithelium (Ricketts et al. 1991), but increases in in situ carcinomas (Karayiannakis et al. 1996). The expression pattern of ER $\beta$ is opposite that of $E R \alpha$, suggesting that loss of ER $\beta$ expression indicates breast cancer development and/or progression (Shaaban et al. 2003). Following ligand binding, classical ERs dimerize and bind to estrogen response elements in the promoters of target genes. Recruitment of co-regulators results in the formation of complexes that mediate transcription (Nilsson et al. 2001). The plethora of cell-specific co-activators and co-repressors account, in part, for the partial agonist versus antagonist activities of tamoxifen in the uterus, breast, bone, and cardiovascular system.

Similar to the differential binding dynamics of the three lactogens to the PRLR (Gertler et al. 1996), the various estrogenic ligands can induce distinct changes in ER conformation, thereby altering co-factor recruitment and receptor stability (Bai \& Gust 2009). This is exemplified by an induction of rapid ER $\alpha$ degradation by the pure ER antagonist ICI 182780 , but not by $E_{2}$ or tamoxifen (Van Den Bemd et al. 1999). The ERs also regulate transcription via protein-protein interactions with transcription factors such as the Fos-Jun complex (Normanno et al. 2005).

Estrogens can rapidly activate the MAPK and PI3K/Akt signaling pathways, traditionally associated with membrane receptors (Bjornstrom \& Sjoberg
2005), but the nature of the receptor(s) involved is controversial. In neurons, pituitary and endothelial cells, G-proteins, ion channels, cytoplasmic protein kinases, and adaptor proteins have been implicated (Manavathi \& Kumar 2006, Fox et al. 2009). In breast cancer cells, one model stipulates that a subpopulation of ERs is localized to the cell membrane. Steroid receptors do not have transmembrane or kinase domains and thus are unlikely to be incorporated to the cell membrane as integral proteins. Instead, they may interact via palmitoylation of membraneassociated proteins such as caveolin, striatin, and Sch (Song et al. 2006). Both IGF1 and EGF receptors are involved in tethering $\mathrm{ER} \alpha$ to the membrane and in initiating MAPK and PI3K activation. Although the above model provides an plausible explanation for nongenomic actions of $E_{2}$, it does not explain the rapid actions of some xenoestrogens, which have much lower affinities to $\mathrm{ER} \alpha$ and $\mathrm{ER} \beta$, and yet are active at subnanomolar doses (Watson et al. 2007).

GPR30, a 7-transmembrane domain receptor that signals through trimeric G-proteins, represents a different model by virtue of its direct binding to estrogens (Filardo \& Thomas 2005, Prossnitz et al. 2008). Its actions have mostly been studied in SKBr3 breast cancer cells, which express GPR30 but not classical ERs (Filardo et al. 2000). Estrogen signaling can be restored in the ER-negative MDA-MB-231 cells by transfection with GPR30. Binding of $E_{2}$ to GPR30 stimulates the cAMP pathways through $\mathrm{G} \alpha \mathrm{s}$, and Src through G $\beta \gamma$. Subsequently, heparan-bound EGF is released, activates the EGF receptor and its downstream signaling that include MAPK, PI3K, and phospholipase C (PLC) (Filardo \& Thomas 2005). Both tamoxifen and ICI act as agonists, rather than antagonists, of GPR30. Expression of GPR30 is higher in invasive carcinoma and is associated with larger tumor size, suggesting that it may be a predictor of aggressive disease (Filardo et al. 2006). The relatively high binding affinity of GPR30 to $\mathrm{E}_{2}\left(K_{\mathrm{d}}\right.$ of $3 \mathrm{nM}$ ) makes this receptor a likely mediator of estrogen actions in ER-negative breast cancer cells (Thomas et al. 2005), but its relative role in cells that also express $E R \alpha$ and $E R \beta$ is unclear.

\section{Chemoresistance by estrogens}

In spite of the abundance of man-made or plant-derived estrogen mimetics which can impact on breast cancer, little is known about their potential interactions with anticancer drugs. In addition, only few studies have examined the role of endogenous estrogens in chemoresistance. This oversight is enigmatic because 
stimulation of tumor growth by estrogens involves not only increased cell proliferation but also reduced cell death. This is exemplified by the activation of both the $\mathrm{PI} 3 \mathrm{~K} /$ Akt survival pathway and $\mathrm{Bcl}-2$ antiapoptotic proteins in breast cancer by estrogens (Huang et al. 1997, Rodrik et al. 2005). Perhaps research on anticytotoxic effects of estrogens has been hampered by an adherence to the classification of breast cancer cells into those that express classical ERs (estrogen-responsive) and those that do not (estrogenunresponsive), leading many researchers to ignore cells that do not express ER $\alpha$ or ER $\beta$.

As a follow-up in our studies on antagonism of cisplatin by PRL (LaPensee et al. 2009b), we ask whether $E_{2}$ acts similarly and if so, by what mechanism. Low doses of $\mathrm{E}_{2}(0.01-10 \mathrm{nM})$ abrogate cisplatin toxicity in T47D and MDA-MBA-468 cells by increasing cell proliferation and decreasing apoptosis (LaPensee et al. 2009a). Protection by estrogen occurs in the presence of $\mathrm{ER} \alpha$ and $\mathrm{ER} \beta$ antagonists, in ER $\alpha$-negative MDA-MB-468 cells, and in T47D cells with ER $\beta$ knockdown, indicating independence of classical ERs. Since both cell types express GPR30 (LaPensee et al. 2009c), this receptor is a plausible candidate for transducing survival signals by $\mathrm{E}_{2}$. Future studies should determine whether GPR30 knockdown abrogates the protective effect of $E_{2}$.

Unlike PRL, $E_{2}$ does not alter entry of cisplatin into the nucleus, suggesting that its protective effects occur downstream of DNA damage (LaPensee et al. 2009a). Because previous reports implicated Bcl-2 in estrogeninduced chemoresistance (Teixeira et al. 1995, Huang et al. 1997), we focused on this antiapoptotic protein. Indeed, $\mathrm{E}_{2}$ increases Bcl-2 expression in T47D cells, both in the presence and absence of cisplatin, but does not alter $\mathrm{Bcl}-\mathrm{xL}$ or $\mathrm{Bax}$. A Bcl-2 inhibitor partially abrogates the protection by $\mathrm{E}_{2}$, indicating that alterations in Bcl-2 may be only part of its mechanism of actions (LaPensee et al. 2009a).

Other data support the concept that estrogens confer chemoresistance. For example, MCF7 cells depleted of estrogen are twice as sensitive to doxorubicin than estrogen-treated cells (Teixeira et al. 1995). Estrogen depletion is accompanied by decreased Bcl-2 expression, and $\mathrm{Bcl}-2$ reconstitution restores resistance to doxorubicin. Others reported that modulation of Bcl-2 levels affects cell sensitivity to taxol (Huang et al. 1997). Also, $\mathrm{E}_{2}$ reduced taxol cytotoxicity in cells overexpressing ER $\alpha$, with the cells sensitized to taxol by treatment with the ER $\alpha$ antagonist ICI (Sui et al. 2007). Estrogen also antagonizes taxol- and radiationinduced apoptosis by altering JNK activity (Razandi et al. 2000). A combination of tamoxifen and TRAIL is more effective than each alone in inducing apoptosis in the ER $\alpha$-negative MDA-MB-231 cells, and in arresting tumor growth in xenografts (Lagadec et al. 2008). This sensitization was associated with decreased Bcl-2 and increased Bax levels. Another mechanism by which estrogens can increase chemoresistance is by affecting drug transporters. This was revealed by estrogeninduced increase in cytoplasmic p-glycoprotein in MCF7 cells, which are resistant to doxorubicin cytotoxicity, but not in T47D cells, which are sensitive to the drug (Zampieri et al. 2002).

\section{BPA, breast cancer, and chemoresistance}

BPA is used in the manufacture of polycarbonate plastics and is the constituent of a wide array of consumer products, including plastic food containers, baby bottles, and the lining of metal food cans (Welshons et al. 2006). Migration of BPA into food or water from plastic containers is influenced by the manufacturing process, storage conditions, and heating by users (Kang et al. 2006, Le et al. 2008). Human exposure to BPA is well documented, with BPA detectable at $0.2-10 \mathrm{ng} / \mathrm{ml}$ in serum from most individuals tested (Welshons et al. 2006). Being lipophilic, BPA can accumulate in breast adipose tissue (Fernandez et al. 2007).

The mechanism by which BPA exerts its actions is enigmatic, since its binding affinity for $E R \alpha$ or $E R \beta$ is 10000 - and 1000-fold lower than that of $\mathrm{E}_{2}$ respectively (Kuiper et al. 1998). Yet, BPA at low nanomolar or subnanomolar doses often elicits activities that are similar to those of $\mathrm{E}_{2}$ (Watson et al. 2005, Hugo et al. 2008). It has been suggested that BPA binds differentially within the ligand-binding domain of the ERs or recruits a different set of co-activators (Safe et al. 2002). In addition, estrogen-related receptors (ERRs) may serve as alternative receptors for transmitting BPA signals (Ariazi \& Jordan 2006). Although ERRs do not bind estrogen, ERR $\gamma$ binds BPA with high affinity $\left(K_{\mathrm{d}}\right.$ of $5.5 \mathrm{nM}$; Okada et al. 2008). ERR $\gamma$ is overexpressed in $75 \%$ of breast tumors compared to the normal epithelium (Ariazi et al. 2002). Phytoestrogens have also been identified as ERRs ligands (Ariazi \& Jordan 2006).

BPA rapidly activates nongenomic signaling in many cell types. In MCF7 cells, MAPK and Akt are phosphorylated within $10 \mathrm{~min}$ of BPA exposure, similar to that seen with $\mathrm{E}_{2}$ and other xenoestrogens (Li et al. 2006). BPA at low doses induces rapid influx of calcium in breast cancer cells (Walsh et al. 2005) and rat hippocampal neurons (Tanabe et al. 2006). In cerebellar neurons, Belcher et al. (2005) observed a 
rapid BPA-induced activation of ERK1/2, PKA, and Src family kinases but not PI3K/Akt pathways. BPA at very low doses (0.01-1 $\mathrm{nM})$ rapidly activates cAMP- and cGMP-dependent protein kinase and triggers rapid phosphorylation of CREB in human testicular seminoma cells (Bouskine et al. 2009). These BPA actions are neither reversed by ICI 182780 nor reproduced by $\mathrm{E}_{2}$ or DES, leading the authors to conclude that classical ERs are not involved.

The estrogenic activity of BPA was discovered upon noticing that BPA leaching from autoclaved plastic containers increases growth of MCF7 cells (Krishnan et al. 1993). In spite of its striking structural resemblance to DES, BPA exhibits a much lower binding affinity to either $\mathrm{ER} \alpha$ or $\mathrm{ER} \beta$ (Ben-Jonathan \& Steinmetz 1998). The low binding affinity of BPA to classical ERs explains its inability to exert a strong mitogenic activity in MCF7 cells. One study found increased cell proliferation in response to BPA only at 60000 times higher concentrations than $E_{2}$ (Olsen et al. 2003). Another group confirmed that BPA at a relatively high dose $(1 \mu \mathrm{M})$ showed a modest stimulation of proliferation of MCF7 cells cultured in estrogen-depleted medium, while $\mathrm{E}_{2}$ was effective at subnanomolar concentrations (Hess-Wilson et al. 2006).

Differential gene profiling in response to BPA has also been reported. In one study, BPA induces a different set of genes than $\mathrm{E}_{2}$ in MCF7 cells, and about 15 genes in ER-null MCF7 cells, leading the authors to conclude that at least some of its actions are independent of ER $\alpha$ (Singleton et al. 2004). Another group added BPA to cultures of breast tissue aspirates (Dairkee et al. 2008). Expression profiling revealed that BPA is associated with high grade tumors and decreased patient survival. These data suggest that exposure to BPA may contribute to the establishment and/or maintenance of breast tumors. In both studies, however, the BPA doses were at the upper nanomolar to micromolar levels. A major criticism of studies using BPA at very high doses is that they do not reflect human exposure levels to this compound. Since BPA exhibits a ' $U$ '-shaped dose-dependent curve in MCF7 cells (Samuelsen et al. 2001), extrapolation from its action, or lack of action, at high doses to its presumed activity at low doses can be misleading.

Our study was the first to report that BPA at environmentally relevant concentrations confers chemoresistance (LaPensee et al. 2009c). Similar to the actions of PRL and $E_{2}$, BPA antagonizes multiple anticancer drugs, showing equimolar potency with $\mathrm{E}_{2}$ in opposing cisplatin toxicity. These BPA actions do not appear to be mediated via $\operatorname{ER} \alpha$ and $\operatorname{ER} \beta$, but the receptor involved was not identified (LaPensee et al. 2009c). In addition to GPR30, we found that both MDA-MB-468 and T47D cells express ERR $\gamma$. Given its high binding affinity for ERR $\gamma$, BPA may exert its chemoprotective effects via this receptor. ERR $\gamma$ has been implicated in tamoxifen resistance in a cell line derived from invasive breast carcinoma (Riggins et al. 2008). Studies are underway with siRNA directed against ERR $\gamma$ to examine its involvement in BPA-induced chemoresistance. However, we cannot rule out involvement of as yet unidentified receptor. We are also examining if BPA actions are mediated via genomic versus nongenomic mechanisms.

BPA alone, or in combination with doxorubicin (LaPensee et al. 2009c) or cisplatin (LaPensee et al. 2009a) increases Bcl-2 expression. Treatment with a Bcl-2 inhibitor completely blocks the BPA-induced antagonism of cisplatin, whereas it only partially abrogates protection by $E_{2}$. This suggests that BPA and estrogen may exert protection against cytotoxicity by somewhat different mechanisms, i.e. antiapoptosis versus mitogenesis. This notion is supported by flow cytometry and BrdU incorporation showing that BPA alone increases cell survival, while estrogen alone increased cell proliferation. Figure 3 schematically illustrates the role of $\mathrm{Bcl}-2$ antiapoptotic protein in mediating chemoresistance by BPA. Note that the mechanism by which BPA exerts chemoresistance against cisplatin differs from that caused by PRL (see Fig. 2).

\section{Summary and perspectives}

Hormones have long been implicated in the pathogenesis of breast cancer, but only a few studies have addressed their role in chemoresistance. Mounting evidence indicates that low doses of PRL, $\mathrm{E}_{2}$, and BPA antagonize multiple anticancer drugs that induce cell death by different mechanisms. PRL opposes cisplatin by increasing GST activity, while $\mathrm{E}_{2}$ and BPA act by increasing Bcl-2 expression. This serves as an excellent example of why targeting one mechanism of resistance may not be sufficient for slowing down tumor growth or eliminating metastases. Future studies should examine in more detail the potential crosstalk between PRL and $\mathrm{E}_{2}$ in conferring resistance, and expand in vitro studies to pre-clinical models. FDA-approved inhibitors of PRL or $E_{2}$, e.g. bromocriptine and tamoxifen, should provide for an easy transition from animal models to clinical trials. As for PRL, blockade of the receptor should be more effective than attempting to reduce the hormone itself. 


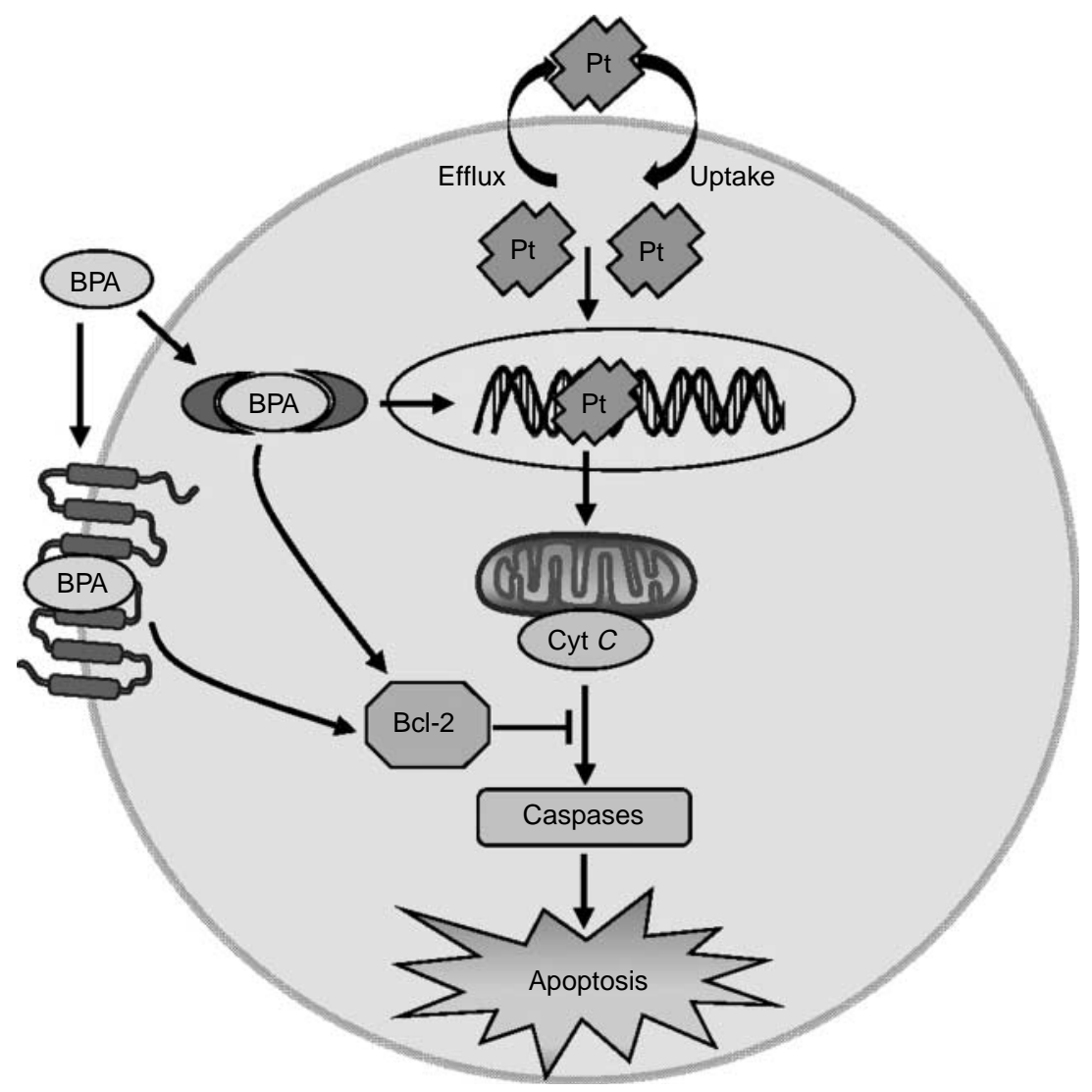

Figure 3 Proposed mechanism by which bisphenol A (BPA) antagonizes cisplatin-induced apoptosis in breast cancer cells. Cisplatin $(\mathrm{Pt})$ diffuses into the cell and enters the nucleus, where it binds to DNA. The ensuing cell cycle arrest leads to the release of mitochondrial cytochrome $C$ (Cyt $C$ ), activation of caspases and apoptosis. BPA binds either to a membrane receptor or diffuses into the cell and binds to a cytoplasmic/nuclear receptor. This results in increased expression of the antiapoptotic protein Bcl-2, which blocks Cyt $C$ release and apoptosis. Estradiol $\left(\mathrm{E}_{2}\right)$ also antagonizes cisplatin-induced apoptosis by activating similar or different mechanisms. Neither the identity of the receptor(s), which mediate the anticytotoxic actions of BPA/E $\mathrm{E}_{2}$, nor the pathway(s) underlying $\mathrm{Bcl}-2$ activation is known.

A reduction in the ability of PRL and estrogens to confer chemoresistance should have several benefits to breast cancer patients, including an increase in the number as well as efficacy of valuable drugs. For example, drugs such as cisplatin, which has shown success in treating many other types of cancers, could be introduced into breast cancer regimens, while the efficacy of already successful anticancer drugs such as taxol could increase. Many treatment regimens use drugs that act by different mechanisms to improve the chances of suppressing tumor growth. Hence, having more options for combination therapy should especially benefit those patients who undergo secondor third-line anticancer treatment. Furthermore, increased efficacy should enable the use of lower drug doses, thereby reducing the toxicity and side effects associated with high dose therapy and improving the quality of life. Finally, because the actions of $\mathrm{E}_{2}$, BPA, and possibly other endocrine disruptors may be independent of ER $\alpha$ and $E R \beta$, patients with ER-negative tumors could benefit from the blockade of $E_{2}$ and estrogen-like compounds.

\section{Declaration of interest}

The authors declare that there is no conflict of interest that could be perceived as prejudicing the impartiality of the research reported.

\section{Funding}

This work was supported by NIH grants ES012212 and CA096613, Center for Environmental Genetics P30 ES06096, Department of Defense grant BC05725, Susan G Komen Breast Cancer Foundation grant BCRT87406 (to N B-J), and NIH training grant 5T32ES007250 (to E W L). 


\section{References}

Aas T, Borresen AL, Geisler S, Smith-Sorensen B, Johnsen H, Varhaug JE, Akslen LA \& Lønning PE 1996 Specific P53 mutations are associated with de novo resistance to doxorubicin in breast cancer patients. Nature Medicine $\mathbf{2}$ 811-814.

Acosta JJ, Munoz RM, Gonzalez L, Subtil-Rodriguez A, Dominguez-Caceres MA, Garcia-Martinez JM, Calcabrini A, Lazaro-Trueba I \& Martin-Perez J 2003 Src mediates prolactin-dependent proliferation of T47D and MCF7 cells via the activation of focal adhesion kinase/Erk1/2 and phosphatidylinositol 3-kinase pathways. Molecular Endocrinology 17 2268-2282.

Ambrosone CB, Sweeney C, Coles BF, Thompson PA, McClure GY, Korourian S, Fares MY, Stone A, Kadlubar FF \& Hutchins LF 2001 Polymorphisms in glutathione$S$-transferases (GSTM1 and GSTT1) and survival after treatment for breast cancer. Cancer Research $\mathbf{6 1}$ 7130-7135.

Ariazi EA \& Jordan VC 2006 Estrogen-related receptors as emerging targets in cancer and metabolic disorders. Current Topics in Medicinal Chemistry 6 203-215.

Ariazi EA, Clark GM \& Mertz JE 2002 Estrogen-related receptor alpha and estrogen-related receptor gamma associate with unfavorable and favorable biomarkers, respectively, in human breast cancer. Cancer Research 62 6510-6518.

Asai-Sato M, Nagashima Y, Miyagi E, Sato K, Ohta I, Vonderhaar BK \& Hirahara F 2005 Prolactin inhibits apoptosis of ovarian carcinoma cells induced by serum starvation or cisplatin treatment. International Journal of Cancer 115 539-544.

Bachman KE \& Park BH 2005 Duel nature of TGF-beta signaling: tumor suppressor vs. tumor promoter. Current Opinion in Oncology 17 49-54.

Bai Z \& Gust R 2009 Breast cancer, estrogen receptor and ligands. Archiv der Pharmazie 342 133-149.

Bargou RC, Wagener C, Bommert K, Mapara MY, Daniel PT, Arnold W, Dietel M, Guski H, Feller A, Royer HD et al. 1996 Overexpression of the death-promoting gene bax-alpha which is downregulated in breast cancer restores sensitivity to different apoptotic stimuli and reduces tumor growth in SCID mice. Journal of Clinical Investigation 97 2651-2659.

Belcher SM, Le HH, Spurling L \& Wong JK 2005 Rapid estrogenic regulation of extracellular signal- regulated kinase 1/2 signaling in cerebellar granule cells involves a $\mathrm{G}$ protein- and protein kinase A-dependent mechanism and intracellular activation of protein phosphatase $2 \mathrm{~A}$. Endocrinology 146 5397-5406.

Bellail AC, Qi L, Mulligan P, Chhabra V \& Hao C 2009 TRAIL agonists on clinical trials for cancer therapy: the promises and the challenges. Reviews on Recent Clinical Trials 4 34-41.

Ben-Jonathan N \& Steinmetz R 1998 Xenoestrogens: the emerging story of bisphenol A. Trends in Endocrinology and Metabolism 9 124-128.
Ben-Jonathan N, Mershon JL, Allen DL \& Steinmetz RW 1996 Extrapituitary prolactin: distribution, regulation, functions, and clinical aspects. Endocrine Reviews 17 639-669.

Ben-Jonathan N, Liby K, McFarland M \& Zinger M 2002 Prolactin as an autocrine/paracrine growth factor in human cancer. Trends in Endocrinology and Metabolism 13 245-250.

Ben-Jonathan N, LaPensee CR \& LaPensee EW 2008 What can we learn from rodents about prolactin in humans? Endocrine Reviews 29 1-41.

Birnbaum LS \& Fenton SE 2003 Cancer and developmental exposure to endocrine disruptors. Environmental Health Perspectives 111 389-394.

Bjornstrom L \& Sjoberg M 2005 Mechanisms of estrogen receptor signaling: convergence of genomic and nongenomic actions on target genes. Molecular Endocrinology 19 833-842.

Blanc C, Deveraux QL, Krajewski S, Janicke RU, Porter AG, Reed JC, Jaggi R \& Marti A 2000 Caspase-3 is essential for procaspase- 9 processing and cisplatin-induced apoptosis of MCF-7 breast cancer cells. Cancer Research 60 4386-4390.

Bouskine A, Nebout M, Brucker-Davis F, Benahmed M \& Fenichel P 2009 Low doses of bisphenol A promote human seminoma cell proliferation by activating PKA and PKG via a membrane G-protein-coupled estrogen receptor. Environmental Health Perspectives 117 1053-1058.

Brockman JL, Schroeder MD \& Schuler LA 2002 PRL activates the cyclin D1 promoter via the Jak2/Stat pathway. Molecular Endocrinology 16 774-784.

Carver KC, Arendt LM \& Schuler LA 2009 Complex prolactin crosstalk in breast cancer: new therapeutic implications. Molecular and Cellular Endocrinology 307 1-7.

Chakravarti P, Henry MK \& Quelle FW 2005 Prolactin and heregulin override DNA damage-induced growth arrest and promote phosphatidylinositol-3 kinase-dependent proliferation in breast cancer cells. International Journal of Oncology 26 509-514.

Chang BD, Swift ME, Shen M, Fang J, Broude EV \& Roninson IB 2002 Molecular determinants of terminal growth arrest induced in tumor cells by a chemotherapeutic agent. PNAS 99 389-394.

Chen WY, Ramamoorthy P, Chen N, Sticca R \& Wagner TE 1999 A human prolactin antagonist, hPRL-G129R, inhibits breast cancer cell proliferation through induction of apoptosis. Clinical Cancer Research 5 3583-3593.

Chen NY, Holle L, Li W, Peirce SK, Beck MT \& Chen WY 2002 In vivo studies of the anti-tumor effects of a human prolactin antagonist, hPRL-G129R. International Journal of Oncology 20 813-818.

Clapp C, Thebault S \& Martinez de la EG 2008 Role of prolactin and vasoinhibins in the regulation of vascular function in mammary gland. Journal of Mammary Gland Biology and Neoplasia 13 55-67. 
Clevenger CV, Gadd SL \& Zheng J 2009 New mechanisms for PRLr action in breast cancer. Trends in Endocrinology and Metabolism 20 223-229.

Coley HM 2008 Mechanisms and strategies to overcome chemotherapy resistance in metastatic breast cancer. Cancer Treatment Reviews 34 378-390.

Dairkee SH, Seok J, Champion S, Sayeed A, Mindrinos M, Xiao W, Davis RW \& Goodson WH 2008 Bisphenol A induces a profile of tumor aggressiveness in high-risk cells from breast cancer patients. Cancer Research 68 2076-2080.

Decatris MP, Sundar S \& O’byrne KJ 2004 Platinum-based chemotherapy in metastatic breast cancer: current status. Cancer Treatment Reviews 30 53-81.

Duan L, Sterba K, Kolomeichuk S, Kim H, Brown PH \& Chambers TC 2007 Inducible overexpression of c-Jun in MCF7 cells causes resistance to vinblastine via inhibition of drug-induced apoptosis and senescence at a step subsequent to mitotic arrest. Biochemical Pharmacology 73 481-490.

Duan R, Ginsburg E \& Vonderhaar BK 2008 Estrogen stimulates transcription from the human prolactin distal promoter through AP1 and estrogen responsive elements in T47D human breast cancer cells. Molecular and Cellular Endocrinology 281 9-18.

Falconer IR 2006 Are endocrine disrupting compounds a health risk in drinking water? International Journal of Environmental Research and Public Health $\mathbf{3}$ 180-184.

Ferlini C, Raspaglio G, Mozzetti S, Distefano M, Filippetti F, Martinelli E, Ferrandina G, Gallo D, Ranelletti FO \& Scambia G 2003 Bcl-2 down-regulation is a novel mechanism of paclitaxel resistance. Molecular Pharmacology 64 51-58.

Fernandez MF, Arrebola JP, Taoufiki J, Navalon A, Ballesteros O, Pulgar R, Vilchezb JL \& Oleaa N 2007 Bisphenol-A and chlorinated derivatives in adipose tissue of women. Reproductive Toxicology 24 259-264.

Filardo EJ \& Thomas P 2005 GPR30: a seven-transmembrane-spanning estrogen receptor that triggers EGF release. Trends in Endocrinology and Metabolism 16 362-367.

Filardo EJ, Quinn JA, Bland KI \& Frackelton AR Jr 2000 Estrogen-induced activation of Erk-1 and Erk-2 requires the $\mathrm{G}$ protein-coupled receptor homolog, GPR30, and occurs via trans-activation of the epidermal growth factor receptor through release of HB-EGF. Molecular Endocrinology 14 1649-1660.

Filardo EJ, Graeber CT, Quinn JA, Resnick MB, Giri D, DeLellis RA, Steinhoff MM \& Sabo E 2006 Distribution of GPR30, a seven membrane-spanning estrogen receptor, in primary breast cancer and its association with clinicopathologic determinants of tumor progression. Clinical Cancer Research 12 6359-6366.

Foster PA 2008 Steroid metabolism in breast cancer. Minerva Endocrinologica 33 27-37.
Fox EM, Andrade J \& Shupnik MA 2009 Novel actions of estrogen to promote proliferation: integration of cytoplasmic and nuclear pathways. Steroids 74 622-627.

Friedrich K, Wieder T, Von Haefen C, Radetzki S, Janicke R, Schulze-Osthoff K, Dörken B \& Daniel PT 2001 Overexpression of caspase-3 restores sensitivity for drug-induced apoptosis in breast cancer cell lines with acquired drug resistance. Oncogene 20 2749-2760.

Gerlo S, Davis JR, Mager DL \& Kooijman R 2006 Prolactin in man: a tale of two promoters. BioEssays $\mathbf{2 8}$ 1051-1055.

Gertler A, Grosclaude J, Strasburger CJ, Nir S \& Djiane J 1996 Real-time kinetic measurements of the interactions between lactogenic hormones and prolactin-receptor extracellular domains from several species support the model of hormone-induced transient receptor dimerization. Journal of Biological Chemistry 271 24482-24491.

Goffin V, Bernichtein S, Touraine P \& Kelly PA 2005 Development and potential clinical uses of human prolactin receptor antagonists. Endocrine Reviews 26 400-422.

Gonzalez L, Zambrano A, Lazaro-Trueba I, Lopez E, Gonzalez JJ, Martin-Perez J \& Aranda A 2009 Activation of the unliganded estrogen receptor by prolactin in breast cancer cells. Oncogene 28 1298-1308.

Gray J, Evans N, Taylor B, Rizzo J \& Walker M 2009 State of the evidence: the connection between breast cancer and the environment. International Journal of Occupational and Environmental Health 15 43-78.

Gutzman JH, Nikolai SE, Rugowski DE, Watters JJ \& Schuler LA 2005 Prolactin and estrogen enhance the activity of activating protein 1 in breast cancer cells: role of extracellularly regulated kinase 1/2-mediated signals to c-fos. Molecular Endocrinology 19 1765-1778.

Henkels KM \& Turchi JJ 1999 Cisplatin-induced apoptosis proceeds by caspase-3-dependent and -independent pathways in cisplatin-resistant and -sensitive human ovarian cancer cell lines. Cancer Research 59 3077-3083.

Hess-Wilson JK, Boldison J, Weaver KE \& Knudsen KE 2006 Xenoestrogen action in breast cancer: impact on ER-dependent transcription and mitogenesis. Breast Cancer Research and Treatment 96 279-292.

Higgins CF 2007 Multiple molecular mechanisms for multidrug resistance transporters. Nature 446 749-757.

Howell SJ, Anderson E, Hunter T, Farnie G \& Clarke RB 2008 Prolactin receptor antagonism reduces the clonogenic capacity of breast cancer cells and potentiates doxorubicin and paclitaxel cytotoxicity. Breast Cancer Research 10 R68.

Hsu PC, Hour TC, Liao YF, Hung YC, Liu CC, Chang WH, Kao MC, Tsay G, Hung HC \& Liu GY 2006 Increasing ornithine decarboxylase activity is another way of prolactin preventing methotrexate-induced apoptosis: crosstalk between ODC and BCL-2. Apoptosis 11 389-399. 
Huang Y, Ray S, Reed JC, Ibrado AM, Tang C, Nawabi A \& Bhalla K 1997 Estrogen increases intracellular p26Bcl-2 to $\mathrm{p} 21 \mathrm{Bax}$ ratios and inhibits taxol-induced apoptosis of human breast cancer MCF-7 cells. Breast Cancer Research and Treatment 42 73-81.

Huang Y, Fang Y, Wu J, Dziadyk JM, Zhu X, Sui M \& Fan W 2004 Regulation of Vinca alkaloid-induced apoptosis by NF-kappaB/IkappaB pathway in human tumor cells. Molecular Cancer Therapeutics 3 271-277.

Hugo ER, Brandebourg TD, Woo JG, Loftus J, Alexander JW \& Ben-Jonathan N 2008 Bisphenol A at environmentally relevant doses inhibits adiponectin release from human adipose tissue explants and adipocytes. Environmental Health Perspectives 116 1642-1647.

Imai Y, Ishikawa E, Asada S \& Sugimoto Y 2005 Estrogenmediated post transcriptional down-regulation of breast cancer resistance protein/ABCG2. Cancer Research $\mathbf{6 5}$ 596-604.

Jongen VH, Hollema H, Van Der Zee AG \& Heineman MJ 2006 Aromatase in the context of breast and endometrial cancer - a review. Minerva Endocrinologica 31 47-60.

Kang JH, Kondo F \& Katayama Y 2006 Human exposure to bisphenol A. Toxicology 226 79-89.

Karayiannakis AJ, Bastounis EA, Chatzigianni EB, Makri GG, Alexiou D \& Karamanakos P 1996 Immunohistochemical detection of oestrogen receptors in ductal carcinoma in situ of the breast. European Journal of Surgical Oncology 22 578-582.

Kelland L 2007 The resurgence of platinum-based cancer chemotherapy. Nature Reviews. Cancer 7 573-584.

Kennedy RD, Quinn JE, Mullan PB, Johnston PG \& Harkin DP 2004 The role of BRCA1 in the cellular response to chemotherapy. Journal of the National Cancer Institute 96 1659-1668.

Krishnan AV, Stathis P, Permuth SF, Tokes L \& Feldman D 1993 Bisphenol-A: an estrogenic substance is released from polycarbonate flasks during autoclaving. Endocrinology 132 2279-2286.

Kuiper GG, Lemmen JG, Carlsson B, Corton JC, Safe SH, van der Saag PT, van der Burg B \& Gustafsson JA 1998 Interaction of estrogenic chemicals and phytoestrogens with estrogen receptor beta. Endocrinology 139 4252-4263.

Lagadec C, Adriaenssens E, Toillon RA, Chopin V, Romon R, Van CF, Hondermarck H \& Le Bourhis X 2008

Tamoxifen and TRAIL synergistically induce apoptosis in breast cancer cells. Oncogene 27 1472-1477.

LaPensee EW, Fox S, Schwemberger SJ, Afton S \& Ben-Jonathan N $2009 a$ Bisphenol A and estradiol are equipotent in antagonizing cisplatin cytotoxicity in breast cancer cells. Cancer Letters [in press].

LaPensee EW, Schwemberger SJ, LaPensee CR, Bahassi EM, Afton SE \& Ben-Jonathan N 2009b Prolactin confers resistance against cisplatin in breast cancer cells by activating glutathione- $S$-transferase. Carcinogenesis 30 1298-1304.
LaPensee EW, Tuttle TR, Fox SR \& Ben-Jonathan N 2009c Bisphenol A at low nanomolar doses confers chemoresistance in estrogen receptor-alpha-positive and -negative breast cancer cells. Environmental Health Perspectives 117 175-180.

Le HH, Carlson EM, Chua JP \& Belcher SM 2008 Bisphenol $\mathrm{A}$ is released from polycarbonate drinking bottles and mimics the neurotoxic actions of estrogen in developing cerebellar neurons. Toxicology Letters 176 149-156.

L'Ecuyer T, Allebban Z, Thomas R \& Vander HR 2004 Glutathione-S-transferase overexpression protects against anthracycline-induced H9C2 cell death. American Journal of Physiology. Heart and Circulatory Physiology 286 H2057-H2064.

Lewis-Wambi JS \& Jordan VC 2009 Estrogen regulation of apoptosis: how can one hormone stimulate and inhibit? Breast Cancer Research 11206.

Li X, Zhang S \& Safe S 2006 Activation of kinase pathways in MCF-7 cells by 17beta-estradiol and structurally diverse estrogenic compounds. Journal of Steroid Biochemistry and Molecular Biology 98 122-132.

Liby K, Neltner B, Mohamet L, Menchen L \& Ben-Jonathan N 2003 Prolactin overexpression by MDA-MB-435 human breast cancer cells accelerates tumor growth. Breast Cancer Research and Treatment 79 241-252.

Lissoni P, Vaghi M, Ardizzoia A, Fumagalli E, Tancini G, Gardani G, Conti A \& Maestroni GJ 2001 Efficacy of monochemotherapy with docetaxel (taxotere) in relation to prolactin secretion in heavily pretreated metastatic breast cancer. Neuroendocrinology Letters 22 27-29.

Lissoni P, Bucovec R, Malugani F, Ardizzoia A, Villa S, Gardani GS, Vaghi M \& Tancini G 2002 A clinical study of taxotere versus taxotere plus the antiprolactinemic agent bromocriptine in metastatic breast cancer pretreated with anthracyclines. Anticancer Research 22 1131-1134.

Llovera M, Pichard C, Bernichtein S, Jeay S, Touraine P, Kelly PA \& Goffin V 2000 Human prolactin (hPRL) antagonists inhibit hPRL-activated signaling pathways involved in breast cancer cell proliferation. Oncogene 19 4695-4705.

Luquita MG, Catania VA, Sanchez-Pozzi EJ, Vore M \& Mottino AD 1999 Prolactin increases the hepatic content of mu-class subunits of glutathione-S-transferase in the rat. Drug Metabolism and Disposition 27 122-124.

Manavathi B \& Kumar R 2006 Steering estrogen signals from the plasma membrane to the nucleus: two sides of the coin. Journal of Cellular Physiology 207 594-604.

Martin JH, Crotty S \& Nelson PN 2007 Phytoestrogens: perpetrators or protectors? Future Oncology 3 307-318.

Maus MV, Reilly SC \& Clevenger CV 1999 Prolactin as a chemoattractant for human breast carcinoma. Endocrinology 140 5447-5450.

McHale K, Tomaszewski JE, Puthiyaveettil R, Livolsi VA \& Clevenger CV 2008 Altered expression of prolactin receptor-associated signaling proteins in human breast carcinoma. Modern Pathology 21 565-571. 
McIlwain CC, Townsend DM \& Tew KD 2006 Glutathione$S$-transferase polymorphisms: cancer incidence and therapy. Oncogene 25 1639-1648.

Mense SM, Hei TK, Ganju RK \& Bhat HK 2008 Phytoestrogens and breast cancer prevention: possible mechanisms of action. Environmental Health Perspectives 116 426-433.

Nabholtz JM, Mouret-Reynier MA, Durando X, Van IP, Al-Sukhun S, Ferriere JP \& Chollet P 2009 Comparative review of anastrozole, letrozole and exemestane in the management of early breast cancer. Expert Opinion on Pharmacotherapy 10 1435-1447.

Nevalainen MT, Xie J, Torhorst J, Bubendorf L, Haas P, Kononen J, Sauter G \& Rui H 2004 Signal transducer and activator of transcription-5 activation and breast cancer prognosis. Journal of Clinical Oncology 22 2053-2060.

Nilsson S, Makela S, Treuter E, Tujague M, Thomsen J, Andersson G, Enmark E, Pettersson K, Warner M \& Gustafsson JA 2001 Mechanisms of estrogen action. Physiological Reviews 81 1535-1565.

Normanno N, Di Maio M, De Maio E, De Luca A, de Matteis A, Giordano A, Perrone F \& NCI-Naple Breast Cancer Group 2005 Mechanisms of endocrine resistance and novel therapeutic strategies in breast cancer. Endocrine-Related Cancer 12 721-747.

Ocana A \& Pandiella A 2008 Identifying breast cancer druggable oncogenic alterations: lessons learned and future targeted options. Clinical Cancer Research 14 961-970.

Okada H, Tokunaga T, Liu X, Takayanagi S, Matsushima A \& Shimohigashi Y 2008 Direct evidence revealing structural elements essential for the high binding ability of bisphenol A to human estrogen-related receptor-gamma. Environmental Health Perspectives 116 32-38.

Olsen CM, Meussen-Elholm ET, Samuelsen M, Holme JA \& Hongslo JK 2003 Effects of the environmental oestrogens bisphenol A, tetrachlorobisphenol A, tetrabromobisphenol A, 4-hydroxybiphenyl and 4,4'-dihydroxybiphenyl on oestrogen receptor binding, cell proliferation and regulation of oestrogen sensitive proteins in the human breast cancer cell line MCF-7. Pharmacology and Toxicology 92 180-188.

Pasqualini JR, Chetrite G, Blacker C, Feinstein MC, Delalonde L, Talbi M \& Maloche C 1996 Concentrations of estrone, estradiol, and estrone sulfate and evaluation of sulfatase and aromatase activities in pre- and postmenopausal breast cancer patients. Journal of Clinical Endocrinology and Metabolism 81 1460-1464.

Peirce SK, Chen WY \& Chen WY 2001 Quantification of prolactin receptor mRNA in multiple human tissues and cancer cell lines by real time RT-PCR. Journal of Endocrinology 171 R1-R4.

Perks CM, Keith AJ, Goodhew KL, Savage PB, Winters ZE \& Holly JM 2004 Prolactin acts as a potent survival factor for human breast cancer cell lines. British Journal of Cancer 91 305-311.
Perotti C, Liu R, Parusel CT, Bocher N, Schultz J, Bork P, Pfitzner E, Groner B \& Shemanko CS 2008 Heat shock protein-90-alpha, a prolactin-STAT5 target gene identified in breast cancer cells, is involved in apoptosis regulation. Breast Cancer Research 10 R94.

Prossnitz ER, Arterburn JB, Smith HO, Oprea TI, Sklar LA \& Hathaway HJ 2008 Estrogen signaling through the transmembrane $\mathrm{G}$ protein-coupled receptor GPR30. Annual Review of Physiology 70 165-190.

Rabbani A, Finn RM \& Ausio J 2005 The anthracycline antibiotics: antitumor drugs that alter chromatin structure. BioEssays 27 50-56.

Ramamoorthy P, Sticca R, Wagner TE \& Chen WY 2001 In vitro studies of a prolactin antagonist, hPRL-G129R in human breast cancer cells. International Journal of Oncology 18 25-32.

Razandi M, Pedram A \& Levin ER 2000 Plasma membrane estrogen receptors signal to antiapoptosis in breast cancer. Molecular Endocrinology 14 1434-1447.

Ricketts D, Turnbull L, Ryall G, Bakhshi R, Rawson NS, Gazet JC, Nolan C \& Coombes RC 1991 Estrogen and progesterone receptors in the normal female breast. Cancer Research 51 1817-1822.

Riggins RB, Lan JP, Zhu Y, Klimach U, Zwart A, Cavalli LR, Haddad BR, Chen L, Gong T, Xuan J et al. 2008 ERRgamma mediates tamoxifen resistance in novel models of invasive lobular breast cancer. Cancer Research 68 8908-8917.

Rodrik V, Zheng Y, Harrow F, Chen Y \& Foster DA 2005 Survival signals generated by estrogen and phospholipase $\mathrm{D}$ in MCF-7 breast cancer cells are dependent on Myc. Molecular and Cellular Biology 25 7917-7925.

Ruffion A, Al Sakkaf KA, Brown BL, Eaton CL, Hamdy FC \& Dobson PR 2003 The survival effect of prolactin on PC3 prostate cancer cells. European Urology 43 301-308.

Safe SH, Pallaroni L, Yoon K, Gaido K, Ross S \& McDonnell D 2002 Problems for risk assessment of endocrine-active estrogenic compounds. Environmental Health Perspectives 110 (Suppl 6) 925-929.

Samuelsen M, Olsen C, Holme JA, Meussen-Elholm E, Bergmann A \& Hongslo JK 2001 Estrogen-like properties of brominated analogs of bisphenol A in the MCF-7 human breast cancer cell line. Cell Biology and Toxicology 17 139-151.

Santen RJ, Santner SJ, Pauley RJ, Tait L, Kaseta J, Demers LM, Hamilton C, Yue W \& Wang JP 1997 Estrogen production via the aromatase enzyme in breast carcinoma: which cell type is responsible? Journal of Steroid Biochemistry and Molecular Biology 61 267-271.

Sessa C, Guibal A, Del CG \& Ruegg C 2008 Biomarkers of angiogenesis for the development of antiangiogenic therapies in oncology: tools or decorations? Nature Clinical Practice and Oncology 5 378-391. 
Shaaban AM, O'Neill PA, Davies MP, Sibson R, West CR, Smith PH \& Foster CS 2003 Declining estrogen receptorbeta expression defines malignant progression of human breast neoplasia. American Journal of Surgical Pathology 27 1502-1512.

Shiga H, Heath EI, Rasmussen AA, Trock B, Johnston PG, Forastiere AA, Langmacher M, Baylor A, Lee M \& Cullen KJ 1999 Prognostic value of p53, glutathione$S$-transferase pi, and thymidylate synthase for neoadjuvant cisplatin-based chemotherapy in head and neck cancer. Clinical Cancer Research 5 4097-4104.

Siddik ZH 2003 Cisplatin: mode of cytotoxic action and molecular basis of resistance. Oncogene 22 7265-7279.

Simoes-Wust AP, Schurpf T, Hall J, Stahel RA \& Zangemeister-Wittke U 2002 Bcl-2/bcl-xL bispecific antisense treatment sensitizes breast carcinoma cells to doxorubicin, paclitaxel and cyclophosphamide. Breast Cancer Research and Treatment 76 157-166.

Singleton DW, Feng Y, Chen Y, Busch SJ, Lee AV, Puga A \& Khan SA 2004 Bisphenol-A and estradiol exert novel gene regulation in human MCF-7 derived breast cancer cells. Molecular and Cellular Endocrinology 221 47-55.

Song RX, Fan P, Yue W, Chen Y \& Santen RJ 2006 Role of receptor complexes in the extranuclear actions of estrogen receptor alpha in breast cancer. Endocrine-Related Cancer 13 (Suppl 1) S3-S13.

Sui M, Huang Y, Park BH, Davidson NE \& Fan W 2007 Estrogen receptor alpha mediates breast cancer cell resistance to paclitaxel through inhibition of apoptotic cell death. Cancer Research 67 5337-5344.

Sultan AS, Xie J, LeBaron MJ, Ealley EL, Nevalainen MT \& Rui H 2005 Stat5 promotes homotypic adhesion and inhibits invasive characteristics of human breast cancer cells. Oncogene 24 746-760.

Suzuki T, Miki Y, Nakamura Y, Moriya T, Ito K, Ohuchi N \& Sasano H 2005 Sex steroid-producing enzymes in human breast cancer. Endocrine-Related Cancer 12 701-720.

Swaminathan G, Varghese B \& Fuchs SY 2008 Regulation of prolactin receptor levels and activity in breast cancer. Journal of Mammary Gland Biology and Neoplasia 13 81-91.

Tanabe N, Kimoto T \& Kawato S 2006 Rapid Ca(2+) signaling induced by bisphenol A in cultured rat hippocampal neurons. Neuroendocrinology Letters 27 97-104.

Teilum K, Hoch JC, Goffin V, Kinet S, Martial JA \& Kragelund BB 2005 Solution structure of human prolactin. Journal of Molecular Biology 351 810-823.

Teixeira C, Reed JC \& Pratt MA 1995 Estrogen promotes chemotherapeutic drug resistance by a mechanism involving Bcl-2 proto-oncogene expression in human breast cancer cells. Cancer Research 55 3902-3907.

Thomas P, Pang Y, Filardo EJ \& Dong J 2005 Identity of an estrogen membrane receptor coupled to a $G$ protein in human breast cancer cells. Endocrinology 146 624-632.
Touraine P, Martini JF, Zafrani B, Durand JC, Labaille F, Malet C, Nicolas A, Trivin C, Postel-Vinay MC, Kuttenn F et al. 1998 Increased expression of prolactin receptor gene assessed by quantitative polymerase chain reaction in human breast tumors versus normal breast tissues. Journal of Clinical Endocrinology and Metabolism $\mathbf{8 3}$ 667-674.

Townsend DM \& Tew KD 2003 The role of glutathione$S$-transferase in anti-cancer drug resistance. Oncogene 22 7369-7375.

Trock BJ, Leonessa F \& Clarke R 1997 Multidrug resistance in breast cancer: a meta-analysis of MDR1/gp170 expression and its possible functional significance. Journal of the National Cancer Institute 89 917-931.

Tworoger SS \& Hankinson SE 2008 Prolactin and breast cancer etiology: an epidemiologic perspective. Journal of Mammary Gland Biology and Neoplasia 13 41-53.

Utama FE, LeBaron MJ, Neilson LM, Sultan AS, Parlow AF, Wagner KU \& Rui H 2006 Human prolactin receptors are insensitive to mouse prolactin: implications for xenotransplant modeling of human breast cancer in mice. Journal of Endocrinology 188 589-601.

Vacca A, Iurlaro M, Ribatti D, Minischetti M, Nico B, Ria R, Pellegrino A \& Dammacco F 1999 Antiangiogenesis is produced by nontoxic doses of vinblastine. Blood 94 4143-4155.

Van Den Bemd GJ, Kuiper GG, Pols HA \& Van Leeuwen JP 1999 Distinct effects on the conformation of estrogen receptor alpha and beta by both the antiestrogens ICI 164,384 and ICI 182,780 leading to opposite effects on receptor stability. Biochemical and Biophysical Research Communications 261 1-5.

Vonderhaar BK 1999 Prolactin involvement in breast cancer. Endocrine-Related Cancer 6 389-404.

Walsh DE, Dockery P \& Doolan CM 2005 Estrogen receptor independent rapid non-genomic effects of environmental estrogens on $\left[\mathrm{Ca}^{2+}\right] \mathrm{i}$ in human breast cancer cells. Molecular and Cellular Endocrinology 230 23-30.

Wang S \& El Deiry WS 2003 TRAIL and apoptosis induction by TNF-family death receptors. Oncogene 22 8628-8633.

Wang Z, Goulet R III, Stanton KJ, Sadaria M \& Nakshatri H 2005 Differential effect of anti-apoptotic genes Bcl-xL and c-FLIP on sensitivity of MCF-7 breast cancer cells to paclitaxel and docetaxel. Anticancer Research $\mathbf{2 5}$ 2367-2379.

Watson CS, Bulayeva NN, Wozniak AL \& Finnerty CC 2005 Signaling from the membrane via membrane estrogen receptor-alpha: estrogens, xenoestrogens, and phytoestrogens. Steroids 70 364-371.

Watson CS, Bulayeva NN, Wozniak AL \& Alyea RA 2007 Xenoestrogens are potent activators of nongenomic estrogenic responses. Steroids 72 124-134.

Welshons WV, Nagel SC \& vom Saal FS 2006 Large effects from small exposures. III. Endocrine mechanisms mediating effects of bisphenol A at levels of human exposure. Endocrinology 147 S56-S69. 
Wiltshire T, Senft J, Wang Y, Konat GW, Wenger SL, Reed E \& Wang W 2007 BRCA1 contributes to cell cycle arrest and chemoresistance in response to the anticancer agent irofulven. Molecular Pharmacology 71 1051-1060.

Yde CW \& Issinger OG 2006 Enhancing cisplatin sensitivity in MCF-7 human breast cancer cells by down-regulation of Bcl-2 and cyclin D1. International Journal of Oncology 29 1397-1404.

Zampieri L, Bianchi P, Ruff P \& Arbuthnot P 2002 Differential modulation by estradiol of P-glycoprotein drug resistance protein expression in cultured MCF7 and T47D breast cancer cells. Anticancer Research 22 2253-2259.

Zhou J \& Giannakakou P 2005 Targeting microtubules for cancer chemotherapy. Current Medicinal Chemistry: Anti-Cancer Agents 5 65-71.

Zinger M, McFarland M \& Ben-Jonathan N 2003 Prolactin expression and secretion by human breast glandular and adipose tissue explants. Journal of Clinical Endocrinology and Metabolism 88 689-696. 